\title{
FOREST INSECT INVESTIGATIONS IN CANADA 1928
}

\section{By J. M. Swaine}

The major investigations under the direction of the Division of Forest Insects included studies on the spruce budworm, the hemlock looper, the larch sawfly, the western pine bark-beetles, the spruce bark-beetle, Monochamus borers in pine, spruce and balsam, western cedar borer, a series of ecological studies dealing with the causes and development of insect epidemics and a series of biological studies with important forest insects.

\section{SPRUCE BUDWORM.}

Biological investigations with this species were continued in 1928 in the Central Ontario budworm outbreak from a field station near Westree, Ont. The object of these studies is to determine the effect of the natural factors which are influencing the development and spread of the outbreak in that region. It is planned to continue this work from the same station in 1929.

\section{Airplane Dusting Experiments}

Airplane dusting experiments for the control of the spruce budworm were commenced first in Cape Breton Island in 1927. Similar experiments were carried out in 1928 from a base at Westree, Ont. The object of the work was to ascertain the minimum effective dose of poison per acre; to test different brands of calcium arsenate for their relative effectiveness, to study the physical factors affecting airplane dusting such as temperature, humidity and wind velocity and to perfect the mechanics of dust application by airplane. Three brands of calcium arsenate were employed in the experiments.

Nine plots were laid out, each approximately 500 feet wide by 1000 feet long. These plots were chosen to represent the different forest types affected in that outbreak. The plots were laid out and the flight lines thereon marked with flags. In addition to the plots several longer single flight lines were laid out and marked with flags. Owing to the small size of the plots to be treated it was necessary to make the dust application in perfectly still air, such as can be obtained usually only just after daybreak. The dusting commenced on June 17, and was continued during the following two weeks as opportunity offered. Unfortunately the weather conditions were exceedingly unfavorable with frequent rains and very few calm mornings. Hopper trouble developed also and caused unfortunate loss of time. Finally before the dust application was completed the machine was crippled in landing and the work had to be discontinued for the season. Handdusting, which was carried out thereafter, gave some valuable results.

Owing to the unfavorable weather and to the accident which finally 
crippled the plane, we did not obtain the information that we expected, but considerable progress was made both in our knowledge of the amount of dust required and in improving the methods of application.

With the experience that has now been obtained in these two experi, ments, it is hoped to continue the airplane dusting work on a much larger scale in 1929 , using areas at least one-half mile in length, so that the dust could be applied in light winds. It should be noted that while it was necessary to have absolutely calm air for dusting the small plots which were dealt with this year, the work could be carried out satisfactorily in light winds if larger areas were being treated so that the drifting dust cloud would all be effective.

This work was carried out with the co-operation of the Dominion Air Service and the Ontario Forestry Branch. The Air Service provided the dusting plane and its personnel, and the Ontario Forest Branch provided the camp, a camp foreman and such assistance as the entomologists required.

THE HEMLOCK LOOPER.

An outbreak of the hemlock looper in the Muskoka region has seriously defoliated the hemlock stands for the past two seasons. Last summer the Entomological Branch carried out an intensive study of the biology of the insect, the injury caused by the defoliation and the natural factors concerned with the infestation. It is planned to continue this investigation for several years in order, if possible, to determine the exact natural conditions under which these extensive hemlock looper infestations develop and spread.

Last summer the Ontario Forestry Branch undertook an experiment for the control of the Muskoka outbreak by airplane dusting. A new plane was obtained for this purpose, but unfortunately delays occurred in delivery of the plane so that it was impossible to have it ready for dusting in time for the work to be of the greatest effect. A dusting plane was finally ob. tained from the Dominion Air Service to assist in this experiment. A considerable amount of calcium arsenate was applied and it was demonstrated that the hemlock looper caterpillars could be killed by this method effectively with approximately 25 pounds per acre. Owing to the lateness of the application, it was impossible to obtain effective results over a large area. It should be possible, however, to control the Muskoka outbreak by this means next season.

HeMlock LOOPER ON BALSAM-Fir.

Last season the hemlock looper, recently so destructive to hemlock stands in Central Ontario, was discovered causing extensive defoliation in balsam-fir on the north shore of the St. Lawrence beyond the Saguenay river. One of our officers investigated the situation and reported at least 400 square miles of mixed balsam-spruce forest badly defoliated and with every indication of an extension of the outbreak in the coming year. 
This species has long been a destructive enemy of balsam-fir in Newfoundland, and it has caused considerable injury to balsam recently in Wisconsin and Minnesota. The outbreak on hemlock in Ontario has not yet spread to balsam-fir in that region and the infestation in Eastern Quebec appears to be an entirely separate development. It is planned to commence a thorough investigation of these Quebec outbreaks next season and the study should be made jointly by entomologists and foresters. It is probable that -airplane dusting with calcium arsenate could be employed on parts of these balsam outbreaks with satisfactory results.

\section{LARCH SAWFLY INVESTIGATIONS.}

In 1927 a commencement was made in transferring to the eastern forests European parasites of the larch sawfly which had been imported by the Entomological Branch some years before and established in the Spruce Woods and Riding Mountains Reserves in Manitoba apparently with a marked effect in checking the outbreaks in that region. Parasitised sawfly cocoons were shipped from the Spruce Woods Reserve to our Parasite Laboratory at Chatham, Ontario, and the parasites reared therefrom were liberated in an infested larch stand at St. Williams, Ont. This work was continued in a larger way in the summer of $1928^{\circ}$ under the direction of an officer appointed especially for this work, and it is planned to continue the distribution of these useful parasites throughout the sawfly infested areas in both Eastern and Western Canada.

\section{PINE BARK-BEETLE CONTROL IN BRITISH COLUMBIA.}

The extensive Dendroctonus outbreaks in yellow pine in Central British Columbia have, after five years of intensive control operations, been brought satisfactorily under control. This work was carried out by the Provincial and Dominion Forest Services in their respective areas, under the direction of the Dominion Entomological Branch. During the past season very little of this control work remained to be done and it is anticipated that no more will be needed during the next few years. Annual inspections of the forest and the control of incipient investations should suffice to prevent all development of similar outbreaks in the future.

Judging by all previous experiences with these outbreaks in British Columbia and in similar regions in the Western United States, this control work has saved the commercial yellow pine of British Columbia from almost wholesale destruction.

Outbreaks by Dendroctonus monticolae in lodgepole pine have also been dealt with, but, in some cases, with less satisfactory results. In lodgepole pine stands the infestation spreads with such rapidity that, unless the control work is undertaken while the outbreak is very small, there may be little hope of success. One control project in a lodgepole pine infestation was continued in British Columbia last season. 
It is reasonable to believe that these destructive outbreaks could be prevented in the future through an efficient system of annual inspections throughout the infested lodgepole pine stands and the prompt application of control work to each small outbreak as it is discovered. With this end in view, it was arranged between the two Branches that special officers of the Division of Forest Insects stationed in British Columbia should visit the ranger stations of the Canadian Forest Service in lodgepole areas of British Columbia and Alberta and instruct the rangers in detecting and reporting lodgepole pine outbreaks and in applying control measures. This work was continued in 1928 and a similar arrangement has been made with the Provincial Forest Branch. With the admirable system of co-operation that obtains among these three Government organizations, we may confidently look forward to the time when these destructive outbreaks will be prevented throughout the commercial lodgepole pine areas of British Columbia and Alberta.

MONOCHAMUS BEETLE INJURY IN LOGS AND FIRE KILLED TREES.

Several Cerambycid beetles of the genus Monochamus, particularly Monochamus scutellatus Say and Monochamus notatus Drury, attack windfalls, fire-scorched trees and logs of pine, spruce, and balsam fir in Eastern Canada, and are responsible for very extensive losses through their tunnels which are excavated by the larvae deep into the wood. Various methods of control have been employed in the past. Whenever possible, logs which are left in the woods throughout the summer season are secured by booms in lakes or rivers. When it is impossible to place logs in the water they have been protected to a considerable degree by covering the piles with spruce or balsam boughs; but in many cases neither of these methods is possible, as for example, following an extensive fire when the timber must be cut as rapidly as possible and no boughs are available for covering the piles. Extensive tests have been conducted for protecting timber from Monochamus beetles under the varying conditions met with in our woods.

Experiments include covering the piles with boughs, earth, and wire netting, in various combinations; and dusting the piles with insecticides, such as lime sulphur, has also been employed in preliminary tests with marked success. Many thousands of white pine logs, left in the Ontario woods on account of the deep snow last winter, were employed in further experiments this season.

The experimental dusting work was carried on in co-operation with the Gordon Lumber Company of North Bay, the Cockburn Lumber Company of Sturgeon Falls and the McFadden Lumber Company of Spragge, Ont.

The results of the experiments indicate that lime sulphur promises to be an effective agent in the control of Monochamus beetles. The final inspection of the treated material has yet to be made; but judging from the comparison made of the dusted and undusted piles during the latter part of the 
summer, it is expected that the control obtained in this experiment will be over 95 per cent.

Timber to the value of thousands of dollars is destroyed by these borers each year and a large part of this loss may be prevented at a very small cost if lime sulphur dusting proves as effective as the experiments thus far conducted indicate.

\section{ECOLOGICAL STUDIES.}

The development of great outbreaks of forest insects such as the spruce budworm, larch sawfly and hemlock looper, often with apparent suddenness, must depend upon definite peculiarities of their biology and environment, including among others the seasonal history of the insects, the reaction of the trees to the insect attack, and climatic conditions of temperature, moisture, sunlight; and air circulation. In addition to all that has been learned respecting this problem a great deal of careful and very difficult investigation remains to be done. In connection with this general subject, we carried out last season an intensive study of the life-history and habits of the maple leaf cutter, and of the influence of climatic conditions, of forest types and of parasites in relation to its outbreaks. This study was carried on in a maple grove about 11 miles from Ottawa. This grove was studied in cross-section at five different levels, daily records being taken in each of these. The progress of the infestation was studied in three plots laid out within the grove and an analysis was made on station trees, representing as nearly as possible the general condition of the forest. - Many important and new! phases of the question were discovered in the course of this analysis. A vast amount of data was thus accumulated, but it will take several seasons before final results can be announced. A similar series of studies is in progress at the Indian Head Laboratory with insects associated with poplar, especially the forest tent caterpillars.

\section{EUROPEAN BEECH BARK LOUSE INVESTIGATIONS.}

This species was introduced many years ago into the province of Nova Scotia, where it has been an important factor in destroying a very large quantity of native beech. The insect has spread more recently into the province of New Brunswick, and a survey carried out in 1928 has determined that it is already well distributed throughout Westmoreland and Albert counties so that the species will probably spread ultimately throughout the beech stands of Eastern North America. An effort will be made to introduce parasites from Europe in the hope of effecting partial control.

This species is proving a most destructive enemy of the beech under the conditions obtaining in the Maritime Provinces. Its habits and the injury it causes have been investigated. While it can be controlled by oil sprays on small areas, no method has yet been devised for dealing with it effectively under forest conditions. 


\title{
PROBLEMS UNDER INVESTIGATION BY THE DIVISION OF FOREST INSECTS
}

\author{
Entomological Branch, Department of Agriculture, 1928.
}

Spruce Budworm Investigations.-These investigations were restricted this year to areas in the Sudbury district of Ontario, the areas previously studied in Cape Breton and British Columbia. Considerable work on airplane dusting was undertaken to determine the effectiveness of this method of control. Biological studies in all the areas concerned were made throughout the season.

Insects Injurious to Fire-Killed Timber, Windfalls and Logs.-Extensive experiments in Northern Ontario and Quebec on the effects of lime sulphur dusting as a protection against sawyers. Biological studies in New Brunswick.

Destructive Eastern Spruce Bark-Beetle.--Observations mainly confined to areas in Cape Breton Island. Study of ecological factors influencing rate of development and number of broods.

Douglas Fir Bark-beetle-Surveys of infested areas and biological studies.

Satin Moth.-Survey and Control operations on ornamental trees in British Columbia, Agassiz, B.C.

Lecanium Scale.-Control operations and surveys against the imported Lecanium scale infesting park trees in different sections of British Columbia. Surveys and reports on same scale in Nova Scotia.

Pine Bark Beetles.-Extensive studies in the field complimented by large scale experiments to determine various factors of importance in the biology of bark-beetles affecting pine. These studies were carried out in various districts of British Columbia.

Bark-beetle Control Operations in British Columbia.-Direction of cutting operations undertaken by the Provincial and Dominion Forest Branches as a means of control against bark-beetle outbreaks in British Columbia.

Biological Studies of Eastern Bark-Beetles.-Detailed experiments to determine various points in the biology of eastern bark-beetles as yet unknown and having direct bearing on the origin and intensity of infestation. Fredericton, N.B.

Balsam Weevil.-Studies in distribution of this species and notes on its life-history and habits. Fredericton, N.B.

White Pine Weevil.-Effect of different forest types on the intensity of infestations studied in planted sample plots in co-operation with the Forest Branch and the University of New Brunswick. Fredericton, N.B.

Larch Sawfly.-Studies of the effect of defoliation caused by this insect in sample plots at Fredericton, N.B., and in the field in Northern Ontario and in Manitoba.

Larch Sawfly Parasites.-Intensive studies of large stands in which parasites were released some years ago. Notes on the effects of parasites. Rear- 
ing of parasite colonies for liberation in infested stands throughout the country. Headquarters, Chatham, Ont.

Biological Studies of Forest and Shade Tree Insects.-The biology and habits of numerous injurious species were studied in the Laboratories of Fredericton, Ottawa, Indian Head and Vernon, B.C.

Insects Affecting Sugar Maple.-Ecological studies of the insect population of maple groves, with a special reference to the maple leaf cutter and the maple borer carried out in the field and in the laboratory, Ottawa.

Study and Control of Shade Tree Insects in the Prairie Provinces.Ecological studies of insect population of western woodlands with a special reference to forest tent caterpillar and bronze birch borer. Indian Head, Sask.

Animal Community Studies.-Special studies in the relations of various insects occupying a common habitat with notes on the influence of changes in vegetation and on seasonal migrations. Ottawa and Indian Head.

European Beech Bark Louse.-Surveys of the infestation in Nova Scotia and New Brunswick. Fredericton, N.B.

Spruce Chermes.-Studies on the biology and control. Fredericton, N.B.

Western Cedar Borer.-Studies of the effect of infestation on the market value of the infested poles, in co-operation with Dominion Forest Branch, Vancouver, B.C.

Hemlock Looper.-Studies in the biology and distribution of the species. Control operations by means of airplane dusting in Muskoka. Studies of the effect of infestations in various infested districts of Ontario and Quebec.

Leconte's Pine Sawfly.-Studies in biology and control. Ottawa.

Classification, Biology and Control of Bark-beetles in British Columbia.

Classification, Biology and Control of Bark-beetles in Canada.

Classification, Biology and Control of Cerambycidae, Buprestidae and other forest Coleoptera of Canada.

Classification, Biology and Control of Scale Insects of Canada.

Classification, Biology and Control of Forest Lepidoptera.

The Classification and Morphology of Lepidopterous Larvae.

The Classification of the Genus Ips in North America.

The Classification of North American Lepturini. 